Mutual Holding Companies:

Evidence of Conflicts of Interest through Disparate Dividends

\author{
Kenneth A. Carow \\ Indiana University \\ Kelley School of Business \\ 801 West Michigan Street \\ Indianapolis, IN 46202 \\ kcarow@iupui.edu \\ 317-274-2783
}

\author{
Steven R. Cox \\ Indiana University Kokomo \\ 2300 South Washington Street \\ Kokomo, IN 46904 \\ scox@iuk.edu \\ 765-455-9314 \\ Dianne M. Roden \\ Indiana University Kokomo \\ 2300 South Washington Street \\ Kokomo, IN 46904 \\ droden@iuk.edu \\ 765-455-9470
}

Comments are welcome.

April 2003 


\title{
Mutual Holding Companies: \\ Evidence of Conflicts of Interest through Disparate Dividends
}

\begin{abstract}
The mutual holding company (MHC) structure establishes a dual-class stock that creates a unique opportunity to transfer wealth from thrift depositor-owners to new minority shareholders through the disparate payment of dividends. We show that MHCs are priced higher than comparable non-MHCs and dividend policy is a significant component of this valuation. We also show that MHC thrifts pay significantly higher dividends than non-MHC thrifts and that an Office of Thrift Supervision (OTS) ruling reducing the potential for disparate dividends between the two classes of shareholders resulted in lower dividends. These results have policy implications of special significance given that the OTS reversed its position in 2000 and because of the current controversy over the use of the MHC structure in the financial service industry.
\end{abstract}




\section{Mutual Holding Companies: Evidence of Conflicts of Interest through Disparate Dividends}

The conversion of mutual thrifts to stock companies has led to controversy and concern over the potential transfer of wealth from depositor-owners to new shareholders (Masulis (1987), Kroszner and Strahan (1996), Unal (1997), Cagle and Porter (1997), and Cox and Roden (1999)). We demonstrate and test how dividend policy transfers wealth in a mutual holding company (MHC). Recent experience in the mutual thrift industry, which includes two distinct regulatory regimes, provides an opportunity to investigate the MHC ownership structure and develop an effective regulatory model for thrift and insurance MHCs.

In a traditional full demutualization 100 percent of the company is sold to new shareholders. In contrast, when a MHC is used, the maximum amount of stock issued to public shareholders is $49.9 \%$, while the remaining majority shares are owned by the newly created holding company. The original thrift depositors jointly own the MHC and thus own a controlling share of the thrift. However, individual depositors cannot access the accumulated equity or exercise direct control.

The conversion of a mutual company to a stock company can be controversial even when the MHC ownership structure is not used. Proponents of conversions claim that demutualizations raise cash and facilitate future access to capital markets. However, in a mutual, no traditional owners exist to argue for full market price during a conversion to a stock company. As a result, there are skewed economic incentives and clear opportunities to set a low price at the initial public offering (IPO). The new shareholders are often able to purchase their shares at discounted prices that rise dramatically 
subsequent to the IPO. Masulis (1987), Kroszner and Strahan (1996), and Unal (1997) show that stock appreciation on the offer day is related to the pre-conversion value of the thrift that is distributed to the initial investors who purchase the equity of the converting thrift. If insiders purchase a disproportionate amount of the offering, insiders may be able to enhance their wealth at the expense of depositor-owners.

The use of disparate dividends may provide another opportunity to transfer wealth from MHC depositor-owners to minority shareholders. Mutual thrifts are prohibited from paying cash dividends or making capital distributions to depositor-owners (Kroszner and Strahan (1996)). Prior to 1995, when MHC thrifts paid a dividend to minority shareholders, the holding company would simply waive its portion of the dividend. Such disparate dividend distributions increase the value of minority shares that receive dividends at the expense of MHC owners who do not receive dividends. To address this concern, the Office of Thrift Supervision (OTS) passed regulations in 1995 requiring that minority shareholders have their ownership proportionately decreased when a MHC waives its right to dividend payment. The OTS ruling compensates MHC owners with increased proportional ownership and addresses the concerns that minority shareholders are unduly enriched by dividend payments. ${ }^{1}$

Our study examines a sample of thrifts that underwent either traditional full demutualizations (non-MHC) or used a MHC to convert to a stock company. We find that MHC thrifts pay significantly higher dividends than non-MHCs. The MHCs are also priced higher than comparable non-MHC firms and dividend policy is a significant component of this valuation. We also find evidence that the OTS ruling in 1995 reduced

\footnotetext{
${ }^{1}$ Both the OTS and the Federal Deposit Insurance Company (FDIC) expressed similar concerns in the American Banker Washington Watch, May 15, 1995.
} 
the incentives for MHCs to pay higher dividends. Our findings show that dividends paid by MHC thrifts and their stock price premium relative to non-MHCs were significantly reduced after the 1995 regulatory change. The results have clear regulatory implications that are particularly important since the OTS reversed its dividend policy in July 2000. The current OTS policy once more allows MHC thrifts to waive their dividends without requiring a compensating decrease in the minority shareholders' ownership, resulting in a renewed opportunity for the transfer of wealth from MHC depositor-owners to minority shareholders. Event study results, surrounding OTS rulings involving MHC dividend policy, are also consistent with wealth expropriation through dividend policy.

Section I of this paper summarizes the history of thrift conversions and their regulation. Section II discusses the incentives for dividend behavior, draws implications for firm value during different regulatory regimes, and specifies our hypotheses. These implications are tested in Section III, where we describe our empirical methods and the results of our analysis of dividend behavior and firm value. Section IV summarizes our findings and concludes with policy implications.

\section{Background of Conversions and Their Regulation}

\section{A. Traditional Demutualizations}

Originally, most mutual thrift institutions began as local cooperatives where members pooled their savings to finance home mortgages. Mutual thrift managers and directors assert that converting to a publicly traded company strengthens the institution by increasing capital and improving access to capital markets. Kroszner and Strahan (1996) observe that regulators encouraged capital-impaired thrifts to convert to stock organizations during the 1980s to bring new capital into the cash-starved industry. 
Additionally, stockholder scrutiny and equity incentives may enhance incentives to improve performance.

In contrast, the lack of the usual tension between buyers and sellers has led some industry observers to claim that thrift insiders are unjustly enriched. Because mutual thrifts have no clear owners, no shareholders exist to argue for full market price during a conversion to a stock company. This results in skewed economic incentives and opportunities for thrift insiders to profit from setting a low price in the IPO. Unal (1997) and Krozner and Strahan (1996) show that the initial stockholders in a conversion buy the capital that they invested, growth opportunities from the new capital, and the preconversion value of a demutualizing thrift. Maksimovic and Unal (1993), assert that insiders have incentives to influence offer size to obtain a higher offer-day return. They show that greater insider participation is associated with smaller offering amounts, resulting in lower offer prices and larger offer-day returns.

\section{B. Conversions Using a Mutual Holding Company Ownership Structure}

Congress first authorized mutual holding companies in the Competitive Equality Banking Act of 1987. The MHC ownership structure is a special case of dual-class stock. The MHC privately holds one class of stock and minority stockholders publicly own a second class. A MHC structure permits public shareholders to obtain up to $49.9 \%$ of the company shares. These minority shares are publicly held but have restricted voting rights. As expressed in Hudson City Bancorp’s proxy statement, "No cumulative voting means that Hudson City MHC, as the holder of a majority of the shares voted at a meeting of stockholders, may elect all directors of Hudson City Bancorp to be elected at 
that meeting. This could prevent public stockholder representation on Hudson City Bancorp's Board of Directors.”

The MHC, which is jointly owned by depositors, holds the majority of shares. Without a strong participatory depositor base, MHC managers and directors effectively control the thrift. In effect, the MHC structure allows for the benefits of conversion to a stock company (immediate cash infusion, access to capital markets, managerial incentives, etc.), while allowing insider retention of control.

Earlier studies of dual-class stock document that shares with superior voting rights trade at a higher price than shares with inferior voting rights (Lease, McConnell, and Mikkelson (1983), Megginson (1990), Zingales (1995), Rydqvist (1996), and Chung and Kim (1999)). However, Cox and Roden (2002) find that preferential dividend promises to low-vote shareholders reduce the voting premium, providing evidence that voting rights can be priced and purchased with preferential dividends.

Mutual thrifts are prohibited from paying cash dividends or making capital distributions to the depositor-owners. However, stock thrifts operate like other corporations and may pay dividends to their stockholders. Since the MHC ownership structure is a hybrid between the two, it presents unique incentive problems. Minority stockholders can receive dividends, but the MHC owners cannot. If dividends are paid to one group of owners and not the other, opportunities exist to transfer wealth.

Our study is not the first to evaluate conflicts of interest in thrift dividend policy. Kroszner and Strahan (1996) state that the dividend policies of thrifts received little regulatory attention prior to the Federal Deposit Insurance Corporation Improvement Act (FDICIA) in 1991. Unlike commercial banks, thrifts faced no explicit legislative 
restraints on dividend payments relative to capital or earnings. Kroszner and Strahan document that in this pre-FDICIA environment, insolvent and thinly capitalized thrifts continued to pay and even increase dividends during periods of cash shortage. Unlike most unregulated non-financial firms, which rely on provisions in debt contracts to restrict dividend policy, the thrift industry relies on government-insured deposits, that until FDICIA, lacked constraints on dividend payments.

Regulators did not pay specific attention to the dividend payments of thrift MHCs until 1995. Prior to 1995, when a MHC paid a dividend to the minority shareholders, the holding company waived its portion of the dividend with no compensating adjustment to its ownership share. Not only did the minority stockholders receive their share of the thrift's earnings in the form of dividends, but they retained their percentage claim to the retained earnings that increased due to the waiver of the holding company's dividends. In 1995, the OTS passed a regulation requiring that the holding company ownership share of the company increase proportionately by the value of the waived dividends. This OTS policy effectively dilutes the minority shareholders' ownership percentage by the value of the dividends waived by the MHC.

The OTS reversed this position in July 2000 to make the mutual holding company structure more attractive as an alternative to full conversion. The policy reversal again allows MHC thrifts to waive dividends without requiring compensating minority shareholder dilution. The OTS argued that fear of such dilution caused a number of institutions to fully convert to stock form rather than remain as MHCs. ${ }^{2}$

\footnotetext{
${ }^{2}$ When a MHC fully demutualizes, it is referred to as a second-stage conversion. In a second-stage conversion, the shares held by the public shareholders are exchanged for shares of a "new" holding company. Additional shares of the "new" holding company
} 


\section{Incentives for Dividend Behavior and Implications for Firm Value}

Prior to the 1995 OTS ruling that restricted dividends, there was opportunity to transfer wealth from the MHC depositor-owners to the minority shareholders. Table I provides an example to illustrate this potential wealth transfer and the intended impact of the 1995 OTS regulation. The first column shows a thrift that is fully demutualized and has two shares of stock. The thrift pays a $\$ 0.25$ per share dividend ( $\$ 0.50$ total) in each of four years and at the end of the fifth year the company is liquidated at a value of $\$ 20$. Given this set of cash flow assumptions and a 10 percent discount rate, the present value of this fully demutualized firm is $\$ 7.00$ per share. The second set of columns shows an economically identical firm using a mutual holding company structure. For simplicity, we assume that 50 percent of the thrift is held by the MHC and 50 percent held by the "minority" shareholders. Thus, the holding company owns one share and the "minority" shareholders own one share. A dividend is again declared at $\$ 0.25$ per share, but the MHC waives its rights to receive the dividend, resulting in a dividend of $\$ 0.25$ per share only for the "minority" shareholders. Under the OTS regulations prior to 1995, the thrift does not need to make adjustment to the ownership share of the firm. In five years, when the firm is liquidated, the MHC owners and the minority shareholders share equally in the buyout price of the firm (which is increased by the future value of the waived dividends). This simplified example illustrates that while the "minority" shareholders receive 50

are offered to the members of the mutual holding company and to the public in accordance with the plan of conversion. The only way to participate in the second-stage conversion is to purchase shares at the offer price. Thus, "ownership" in the mutual holding company does not imply that the mutual's eligible account holders will be paid the value of their ownership; it only provides eligible account holders the opportunity to purchase additional shares at the subscription price. 
percent of the value of the firm at liquidation; their total cash flows ultimately equal 53 percent of the economic value of the firm. The "minority" shareholders will value their stock at a premium price of $\$ 7.40$ per share compared to $\$ 7.00$ per share for the fully demutualized firm. ${ }^{3}$ When waived dividends do not decrease ownership share for minority shareholders, wealth will be transferred from the MHC depositor-owners. The illustrated wealth transfer would be magnified if the level of dividends or the length of time until liquidation were increased.

In the third set of columns, we demonstrate the impact of the 1995 ruling requiring that MHC depositor-owners be credited with a compensating increase in equity ownership. Through the greater proportionate ownership at liquidation, the MHC owners are able to retain 50 percent of the economic value of the firm. However, in practice, if the OTS does not require adjustments for the time value of money or is lax in enforcement, the MHC owners will not be fully compensated.

The unique nature of the MHC ownership structure provides incentives for thrift insiders to take advantage of opportunities to transfer wealth as illustrated above. Given that management compensation may be based on the value of the publicly traded minority shares, managers have incentives to establish dividend policies consistent with the interests of minority shareholders. In addition, thrift insiders purchase public shares and benefit from the payment of dividends.

Based on the previous literature and the regulatory changes, we develop seven hypotheses. The first three hypotheses are based on the MHCs incentives to pay dividends.

${ }^{3}$ The resulting premium relative to the non-MHC is 6 percent $[(\$ 7.40 / \$ 7.00)-1]$. 
Hypothesis 1: MHCs are more likely to pay dividends than non-MHCs.

Hypothesis 2: MHC dividends are higher than the dividends of non-MHCs.

Hypothesis 3: Following the OTS policy restricting dividend waivers, MHCs reduce their level of dividends.

Given the expected effect of divided policy on MHC stock prices, we posit hypotheses 4 and 5.

Hypothesis 4: The stock values of public offerings of MHC thrifts are reduced by OTS restrictions on dividend waivers.

Hypothesis 5: The level of dividends is directly related to the stock value of the MHC.

The regulatory announcement by the OTS also provides an opportunity to test for wealth effects through the implementation of event-study methodology. Analyzing stock prices, we posit hypotheses 6 and 7 .

Hypothesis 6: The stock prices of MHCs decrease surrounding the 1995 OTC ruling restricting dividend waivers.

Hypothesis 7: The stock price of MHCs increase surrounding the 2000 OTC ruling allowing dividend waivers.

\section{Empirical Methods and Results}

This study examines a sample of thrifts that converted using either a traditional full demutualization (non-MHCs) or a MHC ownership structure. The dividend behavior and firm value are analyzed under regulatory regimes before and after the 1995 OTS ruling.

\section{A. Sample Selection}

The sample is composed of mutual thrifts that performed an initial public offering from 1988 to 2000. Our initial sample was identified by searching the SNL DataSource 
and SNL Securities Monthly Market Report and includes 64 MHCs and 329 thrifts that fully demutualized at the time of their initial public offering. SNL DataSource and SNL Securities Monthly Market Report provide information concerning the pro-forma financial statements, insider holdings, offer price, proceeds, and change in price for the first trading date for both mutual holding company conversions and traditional full demutualizations. ${ }^{4}$ Additional information, including the thrift's first regular dividend payment, is gathered from CRSP, Dow Jones Interactive, Edgar reports, and the FDIC database. The final sample that requires availability of all data includes 61 MHCs and 311 full demutualizations.

\section{B. Results}

\section{B.1. Descriptive Statistics}

Table II provides a summary of the sample by years. Despite a fairly stable number of full demutualizations in 1995 and 1996, the number of MHC conversions declines over this time period. The increase in MHC conversions just prior to the 1995 OTS ruling and the subsequent drop in MHC conversions in 1995 and 1996 provide the first evidence that the OTS ruling, requiring that dividends waived by MHCs be used to decrease the ownership share of minority shareholders, reduced the attractiveness of the MHC structure. ${ }^{5}$

\footnotetext{
${ }^{4}$ Nineteen MHCs are from the SNL Securities Monthly Market Report. Each of these companies fully converted to a stock company subsequent to its initial public offering. When a MHC undergoes a second-stage conversion, SNL DataSource does not retain the original conversion information in their database. Unlike SNL DataSource, SNL Securities Monthly Market Report does not always include measures of pro-forma ROA and capital ratios. For these observations we obtained ROA and capital ratios from the company's SEC filings.

${ }^{5}$ Five of the six MHC conversions in 1995 occurred prior to the OTS publishing their ruling in May. While the number of MHC conversions decreased in 1995 and 1996
} 
Table III provides a summary of the sample characteristics of mutual thrifts that converted to stock companies from 1988 to 2000. In addition to pre-conversion data, pro-forma data is used to reflect the expected impact of the offering. Approximately 79 percent of both non-MHCs and MHCs trade on the NASDAQ exchange. The average pre-conversion assets of thrifts using the mutual holding company structure is $\$ 644$ million compared to $\$ 343$ million for thrifts that chose full demutualizations. While MHC firms are nearly twice as large as non-MHCs, the average conversion proceeds are higher for thrifts that execute full conversions. This is because MHCs sell, on average, only 41 percent of the thrift to new shareholders while the non-MHCs sell 100 percent of the company in a full demutualization. The average pre-conversion equity-to-assets ratio is $7.8 \%$ for non-MHCs and $9.7 \%$ for MHCs. However, due to the greater proportional level of ownership sold during traditional full demutualizations, the average pro-forma equity-to-assets ratio is 22 percent for non-MHCs and 14.6 percent for MHCs. ${ }^{6}$

following the ruling, we do not find a significant reduction in full demutualizations over the same period. The renewed popularity of MHC conversions beginning in 1998 may be due to two rulings passed by the OTS in 1997 and 1998. In August of 1997, the OTS simplified conversion to the MHC structure and in March of 1998, the OTS authorized a new three-tier MHC structure. Neither of these rulings altered the OTS policy on dividends.

${ }^{6}$ A logitistic model of the decision to choose a MHC vs. a non-MHC was also considered. Analysts suggest that MHCs may have less growth potential and suffer from poor performance due to agency problems. We collected income and balance sheet data prior to the IPO and found no significant relation between firm performance, capital levels, or growth. Given that both firms are expected to be capital constrained prior to the transaction, a lack of significant differences is not surprising. Subsequent to the offering, we do find that non-MHCs grow faster. This is consistent with their larger capital acquisition at the IPO. However, subsequent to the conversions, ROA and efficiency ratios suggest that MHCs may have done a better job at putting their new assets to work. We find no evidence that CEO compensation at MHCs exceeds that at non-MHCs. 


\section{B.2. Dividend Policy}

In this subsection, we determine how the dividend policies of mutual holding companies differ from the dividend policies of fully demutualized thrifts. We also show how MHC dividend policy changes subsequent to the OTS ruling requiring that the value of waived dividends decrease the ownership of minority shareholders.

Table IV contains preliminary statistics concerning the dividend policies of nonMHCs and MHCs. Consistent with hypothesis 1, MHCs are more likely to issue dividends. 93.4 percent of MHCs pay dividends within the first year after their initial stock offering, compared to 73.6 percent of non-MHCs. For each thrift, we annualize the company’s first declared dividend and divide it by the company’s book value per share. The estimation of dividend yield is consistent with Ohlson (1995), who states that dividends are paid out of the book value of the firm and, as a result, dividend payments reduce firm market value on a dollar-for-dollar basis. ${ }^{7}$ The average dividend yield for the MHCs (3.33\%) is more than twice that of non-MHCs (1.43\%). To further test the difference in the level of dividends, we limit the sample by excluding firms that did not pay any dividends. The sample of MHCs falls to 57 and the sample of non-MHCs is reduced to 229 observations. The dividend yield for MHCs (3.56\%) remains significantly higher than the dividend yield of non-MHCs that pay dividends (1.94\%), providing preliminary evidence in support of hypothesis 2.

\footnotetext{
${ }^{7}$ Other dividend ratios were also considered. If price is a function of dividends, dividing dividends by the offer price or the price at the close of the first date would bias the results. In place of market prices, dividends are divided by the book value of equity. We also tested the dividend-to-assets ratio and a dividend payout ratio. For the dividend payout ratio, we omit firms that had negative earnings and we restrict the upper limit of this variable to be equal to 100 . Similar cross-sectional results are found when using these alternative definitions.
} 
The results of the cross-sectional tests to explain dividend policies are presented in Table V. The dependent variable is equal to the dividend yield, defined as the annualized dividend in the first year after the demutualization divided by the book value per share. Similar to previous studies by Kroszner and Strahan (1996), Casey and Dickens (2000) and Collins, Blackwell, and Sinkey (1994), the cross-sectional regressions control for the firm's earnings (ROA), capital (equity-to-assets), and size (log of assets). To test hypothesis 2, model 1 also includes an indicator variable equal to one if the firm is a MHC and zero otherwise. Consistent with prior literature, our control variables show that capital is positively related to the level of dividends. For our hypothesis variable, we find that the dividend yield of MHCs is 2.03 percent higher than the dividend yield of non-MHCs.

In 1995, the OTS reduced the incentives for MHCs to issue dividends by requiring that the value of waived dividends be used to decrease the ownership of the minority shareholders. To test hypothesis 3, model 2 adds an indicator variable equal to one if the firm used a MHC structure and the initial stock offering was made after February 1, 1995 and zero otherwise. Subsequent to the OTS ruling, we find that new MHCs pay significantly lower dividends. Prior to February 1, 1995, the average dividend yield of MHCs was 3.16 percent higher than non-MHCs. However, MHCs making an initial stock offering subsequent to February 1995 had an average dividend yield 1.76 percent lower than earlier MHCs and a dividend yield 1.40 (3.16 - 1.76) percent higher than non-MHCs. F-test results reject the hypothesis that the sum of the two indicator variables is equal to zero. This shows that MHCs that went public after the OTS ruling in 
1995 still pay dividends that are significantly higher that non-MHC thrifts but their dividends are significantly lower than those of MHCs formed prior to the ruling.

To further ensure that the test statistics are not simply differentiating between the percent of companies that pay dividends, Model 3 in Table V omits from the analysis any non-MHCs that did not pay any dividends. This restriction eliminates 4 MHCs and 82 non-MHCs from the third model, reducing the sample to 286 observations. Prior to February 1995, the average dividend yield of MHCs was 2.50 percent higher than nonMHCs. Subsequent to February 1995, MHCs undergoing an initial stock offering reduced their dividend yield by 1.32 percent compared to their predecessors. MHCs still have a dividend yield $1.18(2.50$ - 1.32) percent higher than non-MHCs. Once again, Ftest results reject the hypothesis that the sum of the two indicator variables is equal to zero.

The previous analysis focused on differences across firms. In the following table, we focus a within-firm test of dividend policy, by testing if established MHCs change their dividend policy subsequent to the OTS ruling in 1995 . We restrict the sample to firms with at least one complete year of dividend information prior to February 1, 1995 and one complete year of dividend information after February 1, 1995. The sample ultimately includes 8 MHCs and 42 non-MHCs. ${ }^{8}$ Table VI shows that relative to the level of dividend payments in the year prior to the new OTS dividend waiver policy, non-MHC thrifts are more likely than MHCs to increase dividends in the subsequent year and

\footnotetext{
${ }^{8}$ In order to obtain consistent reporting of when dividends were paid relative to the OTS enforcement date, the sample was restricted to thrifts that implemented their dividend policy by early 1994 and have data available on CRSP. If the firm paid semi-annually (quarterly, annually) prior to February 1, 1995 we also required the firm to pay semiannually (quarterly, annually) after February 1, 1995.
} 
MHCs are more likely than non-MHCs to decrease dividends. These findings provide further support for hypothesis 3, showing that the incentive for MHCs to pay dividends decreased subsequent to the OTS ruling. This result is particularly interesting given that the OTS grandfathered firms under their new dividend policy. Thus, these firms were not required to compensate MHC shareholders with an increasing portion of the stock when dividends were paid to minority shareholders.

The results in this section provide evidence that MHCs pay significantly higher dividends than non-MHCs (hypothesis 1 and 2). Furthermore, restrictions on dividend policy by the OTS significantly reduce the incentives for MHCs to pay higher dividends (hypothesis 3).

\section{B.3. Firm Value}

When determining depository institution pricing, Rhoades (1987) Cheng, Gup, and Wall (1989), Rogowski and Simonson (1989), Frieder and Petty (1991), Rose (1991), Palia (1993), Fraser and Kolari (1988), Shawky, Kilb, and Staas (1996), and Brewer, Jackson, Jagtiani, and Nguyen (2000) each use a measure of the firm's market price divided by its book value. ${ }^{9}$ In this section, we utilize the price-to-book ratio to demonstrate how the value of converting thrifts differs based on the form of conversion and dividend policy. ${ }^{10}$

${ }^{9}$ For MHCs, the number of shares outstanding includes the shares held by minority stockholders and the shares held by the MHC. Using the number of shares outstanding assumes that there is no discrepancy between the pricing of the two dual classes of stock for MHCs. Our null hypothesis assumes no price discrepancy based on dividend policy. ${ }^{10}$ Regulators commonly use three equations to estimate the value of a converting thrift. These equations provide three pricing ratios: price-to-book, price-earnings, and price-toassets. Unal (1997) provides a critical review of the fundamental flaws in the regulatory appraisal equations that were used to estimate the value of a thrift converting from a mutual to a stock charter. Due to these significant biases, we do not directly rely on the 
Preliminary evidence of the pricing variables is provided in Table VII. The average ratio of offer price to book value of shares is 64.8 percent for non-MHCs and 93.5 percent for MHCs. Similarly, the average first day close price-to-book value of shares is 78.4 percent for non-MHCs and 112.3 percent for MHCs. These significant differentials are evidence that thrift mutual holding companies have higher market valuation. While a portion of the premium may be due to dividend policy, the premium may also be attributed to other benefits of the MHC structure or individual firm characteristics. ${ }^{11}$ Table VII also presents the percent change in price on the first trading day. Both MHCs and non-MHCs have similar average one-day stock price increases of approximately 20 percent.

Next, cross-sectional analysis is used to investigate if the mutual holding company structure and subsequent dividend policy are significant determinants of higher pricing for MHCs. We analyze the price-to-book ratio. To calculate the price-to-book ratio we use the offer price as well as the price at the end of the first trading day. ${ }^{12}$

Consistent with previous research on depository institution pricing, we control for return-on-assets, equity-to-assets, and log of size ${ }^{13}$ (Cheng, Gup, and Wall (1989),

appraisal equations or the appraisal estimation reported in the proxy statements. Later alternative ratios will be considered.

${ }^{11}$ Other benefits to minority shareholders may include the potential to dissolve the MHC shares. Under the terms of a merger agreement between North Shore (non-MHC) and Marquette Savings Bank (MHC), North Shore agreed to buy each of the shares not owned by the MHC. The MHC shares were cancelled. The OTS approved this transaction in June (Gallagher 2000).

${ }^{12}$ We also included tests using the price after the $75^{\text {th }}$ trading date to test the robustness of our results. The results from this alternate model lead to similar interpretation and conclusions.

${ }^{13}$ Several authors also suggest a ratio of non-performing loans-to-assets. We do not report using non-performing loans-to-assets in the model since missing observations 
Rogowski and Simonson (1989), Frieder and Petty (1991), Rose (1991), Palia (1993), Fraser and Kolari (1988), Shawky, Kilb, and Staas (1996), and Brewer, Jackson, Jagtiani, and Nguyen (2000)). The industry average price-to-book ratio controls for prevailing thrift market values. This approach allows us to use the primary indicators utilized in prior banking studies and enhance the model using an industry comparable ratio that controls for changes in the market value of banking firms through time. ${ }^{14}$ An indicator variable for insider holdings incorporates the potential for signaling (Leland and Pyle (1977)). Studies by Ritter (1984), Kim, Krinsky, and Lee (1995), Klein (1996) and Van der Goot (1997) find that non-financial IPOs with a larger fraction of the equity retained by insiders have higher market valuations.

In Table VIII, we report regression results using price-to-book as the dependent variable. Models 1 and 3 use the offer price and Models 2 and 4 use the price at the close of the first trading day when calculating the price-to-book ratio. Models 1 and 2 use two indicator variables to determine whether MHCs are priced significantly higher than nonMHCs. The first indicator variable is equal to one if the firm is a MHC and zero otherwise. To test hypothesis 4 , we define a second indicator variable that is equal to one if the firm is a MHC converting after February 1995 and zero otherwise.

Both models 1 and 2 are highly significant, with adjusted R-squared values of 52 percent and 41 percent, respectively. Model 1 shows that firm size, inside ownership, and the industry average price-to-book ratio are significant control variables. The price-tobook value is lower for larger firms and firms with high inside ownership. The price-to-

reduce our sample size. However, models including non-performing loans result in similar conclusions.

${ }^{14}$ We obtain similar results when we remove the industry average price-to-book ratios and replace these values with yearly indicator variables (Brewer et al (2000)). 
book is higher when the industry price-to-book ratio is higher. Controlling for these factors, MHCs making an initial stock offer prior to the 1995 OTS ruling have a significantly higher price-to-book ratio than non-MHCs. On average, the stock price of these MHCs has a 35 percent higher price-to-book value relative to non-MHCs. MHCs that made their initial stock offering subsequent to the 1995 OTS ruling have a 12 percent lower price-to-book value than MHCs that made their initial stock offering prior to the 1995 OTS ruling. Thus, the premium drops from 35 percent prior to the OTS ruling to 23 percent subsequent to the OTS ruling. An F-test rejects the hypothesis that the sum of the two indicator variables is equal to zero. The persistence of the premium may be due to the potential for lax enforcement, reversal of the ruling, or other benefits to the MHC structure. $^{15,16}$

The primary difference between Model 1 and Model 2 is that the price-to-book ratio is calculated using the closing price at the end of the first trading day. In contrast to the results of Model 1, firm size and insider ownership are both insignificant. This is consistent with greater underpricing for converting thrifts where insiders acquire greater holdings as documented by Maksimovic and Unal (1993) and Cox and Roden (1999).

${ }^{15}$ Based on the July 12, 2000 Federal Register, the OTS provided only lax enforcement of their dividend-policy regulation. The article states that, although the OTS required some dilution for special or excess dividends, it typically did not require dilution for ordinary dividends. The Federal Register also stated that after July 12, 2000, the "OTS will no longer require dilution for any waived dividend in a subsequent conversion to stock.”

${ }^{16}$ Alternatively, since the MHC depositor shares are not traded, assuming the value of the minority shares equals the value of the MHC depositor shares may create an upward bias in price-to-book ratios. If MHC shares, as a dual-class of stock have a lower valuation, the indicator for MHCs would proxy for this difference. Additional tests were also performed to ensure that alternative calculations of price-to-book ratios did not significantly influence the conclusions. Even if the MHC depositor shares are assumed to have zero value when calculating price-to-book ratios, we obtain similar results. 
Providing additional support for hypothesis 4 , model 2 also shows that premiums decrease after February of 1995.

Earlier we demonstrated how dividends could be used to transfer wealth from the MHC depositor-owners to the minority shareholders and we documented that MHCs pay significantly higher dividends than non-MHCs. Given the potential for wealth transfer through dividend policy, Models 3 and 4 in Table VIII test whether dividend policy influences the value of MHCs. In addition to the control variables and MHC indicator variable used in Models 1 and 2, we incorporate three new explanatory variables in Models 3 and $4 .{ }^{17}$ The first new variable is equal to the dividend yield on non-MHCs and zero otherwise. The second variable is equal to the dividend yield on MHCs that made their initial stock issuance prior to the February 1995 ruling and zero otherwise. The third variable is equal to the dividend yield on MHCs that made their initial stock issuance after February 1995 and zero otherwise. Dividends are defined as the annualized dividends from the first year subsequent to the conversion. We define dividend yield as a percent of book value for two reasons. First, as discussed earlier, Ohlson (1995) shows that dividends are paid out of a firm's book value. Second, since previous studies of dual-class stock find that differential dividend policy will impact the market value of the firm, defining dividends as a percentage of a firm's current price would violate the assumption of independence.

Model 3 shows that the dividend variables add explanatory power as is evidenced by the improved adjusted R-squared value. The results indicate that dividend policy is not an important indicator of valuation for non-MHCs; however, dividend policy does have a

17 Due to significant problems with multicollinearity, the indicator for MHCs making their initial offering after 1995 is not included. 
significant influence on MHC valuation. As stated in hypothesis 5, dividends have a greater influence on prices prior to the 1995 OTS ruling; however, even after the 1995 OTS ruling, investment banks priced dividend policy.

In Model 4, the price-to-book ratio is based on the offering day closing price. Prior to the 1995 OTS ruling investors consider dividend policy to be a significant factor in pricing MHCs. The value of dividends was reduced after the OTS restricted dividend waivers. Each of these findings supports the conclusion that waiving dividends can transfer wealth from the MHC owner-depositors to minority shareholders. ${ }^{18}$

While the previous analysis centers on price-to-book ratios, the results presented in Table IX reflect investigation of the impact of the MHC structure and dividend policy on stock price returns at the time of the conversion. The dependent variable is equal to the one-day return at the initial public offering. The control variables are the same as in the previous analysis with the addition of variables found significant by Maksimovic and Unal (1993) including the firm-specific price-to-book ratio at the offer date, the percentage change in the thrift index over the previous six weeks, and the percentage change in interest rates over the previous six weeks. The results add further support for the interpretations based on Table VIII. In Model 1 of Table IX, we show that MHCs

${ }^{18}$ Additional models, not reported in the tables, are tested to determine the robustness of our results. Similar to prior studies [Kane and Unal (1990) and Flannery and Houston (1999)] we define the dependent variable as the stock price and include the existing set of independent variables as well as the book value of equity. The results indicate that MHCs prior to February 1995 sold at a premium of $\$ 4.00$ to $\$ 5.00$ per share over nonMHCs. After 1995, the premium remained at approximately $\$ 2.00$ per share. Furthermore, as in the previous results, the dividend yield is a significant determinant of MHC price prior to 1995, but not after the OTS ruling. Price-earnings ratios were also considered as the dependent variable. Using the same independent variables as in Table VIII, we find that MHCs have higher price-earnings ratios and price-earnings ratios are positively related to dividend yield prior to February 1995. 
formed after the 1995 OTS ruling have significantly lower returns than MHCs that went public prior to 1995 (hypothesis 4). In Model 2, we show that after 1995 higher dividends by MHCs resulted in significantly lower offer-day returns, consistent with investors placing a smaller value on dividends after the 1995 OTS ruling (hypothesis 5). ${ }^{19}$

The significance of dividend policy on MHC offer-day returns and price-to-book ratios provide evidence of the value of dividends to minority shareholders when the OTS allowed MHCs to waive dividends without stock compensation. While the significance of the offer-day returns could be due to initial mispricing, the finding that dividend yield is also a significant component of the price-to-book ratio calculated at the close of the offer day provides evidence that minority shareholders value dividends.

\section{B.4. Event Study Support}

To enhance the validity of our conclusions, we also use event-study methodology to test the significance of returns surrounding each of the OTS rulings. We use a standard event-study methodology based on Brown and Warner (1985). Our 100-day estimation period begins 5 days prior to the event. We report cumulative abnormal returns (CARs) for the day of and the day prior to the publication date. In Table X, we report the number of firms used in the study, the mean CAR, the t-statistic testing if the CAR is significantly different from zero, the number of firms with positive and negative CARs, and a Z-statistic testing if the percent of positive returns is significantly different from $50 \%$.

\footnotetext{
19 These results are consistent with the results shown in Model 3 of Table VIII, where it appears that investment bankers continued to value the higher dividends when setting their offer-day price subsequent to the OTS ruling. Investors, however, recognized that dividends were not a significant factor in determining prices subsequent to the OTS ruling as shown in Model 4 of Table VIII.
} 
On May 15, 1995, the OTS announced that MHCs must seek a dividend waiver on a case-by-case basis. The OTS policy required that minority shareholders have their ownership proportionately decreased when a MHC waives its right to dividend payments. Companies in existence prior to February 1, were allowed to continue waiving dividends. The mean CAR surrounding this event was $-0.38 \%$, insignificantly different from zero. While this would be viewed as a negative event for new MHCs (hypothesis 6), given that existing MHCs were grandfathered under the prior regulations, an insignificant result is not surprising.

On July 12, 2000, the OTS repealed their previous ruling and no longer required dilution for waived dividends. Even though the OTC frequently waived dividends on a case-by-case basis prior to this date, the official ruling was well received by minority shareholders. The average cumulative abnormal return for all MHCs on July 12, was 0.59\%, significant at the 5 percent level, with positive CARs for two-thirds of MHCs. To further test the price reaction of the dividend ruling, we reduce the sample, eliminating firms grandfathered in the 1995 ruling and therefore unaffected by the new dividend policy. For the 24 firms directly affected, the average CAR is $0.88 \%$, significant at the 10\% level, with positive CARs for two-thirds of the sample. The significant positive stock price reaction supports hypothesis 7 and provides additional evidence that dividend policy facilitates a transfer of wealth from MHC holders to minority shareholders.

\section{Conclusions}

Mutual holding companies are hybrid structures that facilitate conversion of a mutual to a stock company. Experience in the thrift industry offers an opportunity to 
investigate the effect of dividend policy on the value of MHCs and develop recommendations for all MHCs. The potential growth of the MHC structure is great, with over 12,000 mutual financial institutions in the United States eligible to adopt the MHC structure. The greatest growth potential lies with credit unions, which have successfully converted to mutual saving banks and subsequently formed MHCs to facilitate conversion to stock companies (Merrick (2001)). With this two-stage process, the MHC structure is available to over 10,700 credit unions, 400 mutual thrifts, and 1,360 mutual insurance companies. ${ }^{20}$

The incentives and opportunities for wealth transfer may be even greater for the mutual insurance industry than the mutual thrift industry. On average, mutual insurance companies are much larger than mutual thrifts, allowing for greater wealth transfers. In addition, insurance companies are regulated at the state level while thrifts are more centrally regulated. State regulators and lawmakers may be more likely to rule for local insurance companies because many of the policyholders who could be harmed are likely to live outside of the state. In fact, some mutual insurance companies have used the threat of moving their operations out of state while lobbying their state governments to allow the formation of mutual holding companies. ${ }^{21}$

We document that thrift MHCs have significantly higher dividends than thrifts undergoing full conversions. Dividend yields are the highest for MHCs that went public prior to the 1995 OTS ruling, which required MHC depositor-owners to be compensated

${ }^{20}$ The mutual holding company structure has also been used in France, Germany, Austria, Canada, Netherlands, and Switzerland (Okuba, 1999).

${ }^{21}$ The passage of the Financial Modernization Act of 1999 allows any mutual company to re-domesticate their company into a state that allows the mutual holding company structure. 
for waived dividends by increasing their ownership. Not only do MHCs pay higher dividends, but dividend policy has a significant influence on the value of the minority shares. The stock price of MHCs sells at a premium prior to 1995, when the MHC owner-depositors were not compensated for waived dividends. Furthermore, dividend policy is a significant contributing factor to the premium paid for MHCs, but not a significant factor for pricing non-MHCs. Although it appears that investment bankers continued to value higher dividends when setting MHC offer-day prices subsequent to the 1995 OTS ruling, investors recognized that dividends were no longer a significant valuation factor after the ruling. These results are consistent with dividend policy transferring wealth from MHC depositor-owners to minority stockholders in the absence of regulation.

On July 12, 2000 the OTS proposed the relaxation of regulations on dividends for mutual holding companies, resulting in a significant positive abnormal return for MHC minority stockholders. The positive abnormal return provides additional evidence of the potential for wealth transfer from MHC depositor-owners to minority stockholders.

Our findings demonstrate that consistently enforced regulations of dividend payments to minority shareholders of MHCs are needed to prevent the transfer of wealth from MHC depositor-owners to minority shareholders. Based on these results, we recommend both insurance and thrift regulators require equal dividend payments to each class of stockholders or compensation through increased ownership for MHCs that waive dividends. 


\section{REFERENCES}

Alford, Andrew W., 1992, The effect of the set of comparable firms on the accuracy of the price-earnings valuation method, Journal of Accounting Research 3, 27-32.

Brewer III, Elijah, William E. Jackson III, Julapa A. Jagtiani, and Thong Nguyen, 2000, The price of bank mergers in the 1990s, Economic Perspectives 24, 2-23.

Brown, S. and J. Warner, 1985, Using daily stock returns: The case of event studies, Journal of Financial Economics 14, 3-31.

Cagle, Julie A. and Gary E. Porter, 1997, Conversions of mutual savings institutions: do initial returns from these IPOs provide investors with windfall profits?, Financial Services Review 6, 141-150.

Casey, K. Michael and Ross N. Dickens, 2000, The effects of tax and regulatory changes on commercial bank dividend policy, The Quarterly Review of Economics and Finance 40, 279-293.

Cheng, David C., Benton E. Gup, and Larry D. Wall, 1989, Financial determinants of bank takeovers: Note, Journal of Money Credit and Banking 21, 524-536.

Chung, Kee, and Jeong-Kuk Kim, 1999, Corporate ownership and the value of a vote in an emerging market, Journal of Corporate Finance 5, 35-54.

Collins, M. Cary, David W. Blackwell, and Joseph F. Sinkey, Jr., 1994, Financial innovation, investment opportunities, and corporate policy choices for large bank holding companies, The Financial Review 29, 223-247.

Cox, Steven, and Dianne Roden, 1999, Initial public offerings by mutual thrifts: The regulatory impact, Journal of Economics and Finance 23, 113-122.

Cox, Steven, and Dianne Roden, 2002, The source of value of voting rights and related dividend promises, Journal of Corporate Finance 8, 337-351.

Dunham, Constance., 1985, Mutual-to-stock conversions by thrifts: Implications for soundness, New England Economic Review January/February, 31-45.

Flannery, Mark J. and Joel F. Houston, 1999, The value of government monitor for U.S. banking firms, Journal of Money, Credit and Banking 31, 14-34.

Fraser, Donald R., and James W. Kolari, 1988, Pricing small bank acquisitions, Journal of Retail Banking 10, 23-28.

Frieder, Larry A., Phillip N. Petty, 1991, Determinants of bank acquisition premiums: Issues and Evidence, Contemporary Policy Issue 9, 13-24. 
Gallagher, Kathleen, 2000, North Shore to Buy Marquette Financial, The Milwaukee Journal Sentinel, February 16.

Kane, Edward J., and Haluk Unal, 1990, Modeling structural and temporal variations in the market's valuation of banking firms, Journal of Finance 45, 113-136.

Kaplan, Steven N. and Richard S. Ruback, 1995, The valuation of cash flow forecasts: An empirical analysis, Journal of Finance 50, 1059-1093.

Kim, Jeong-Bon, Itzhak Krinsky, and Jason Lee, 1995, The role of financial variables in the pricing of Korean initial public offerings, Pacific-Basin Finance Journal 3, 449464.

Kim, Moonchul, Jay R. Ritter, 1999, Valuing IPOs, Journal of Financial Economics 53, 409-437.

Klein, April, 1996, The association between the information contained in the prospectus and the price of initial public offerings, Journal of Financial Statement Analysis 2, 23-40.

Kroszner, Randall S., and Philip E. Strahan, 1996, Regulatory incentives and the thrift crisis: Dividends, mutual-to-stock conversions, and financial distress, Journal of Finance 51, 1285-1319.

Lease, Ronald C., John J. McConnell, and Wayne H. Mikkelson, 1983, The market value of control in publicly-traded corporations, Journal of Financial Economics 11, 439471.

Leland, Hayne E. and David H. Pyle, 1977, Informational asymmetries, financial structure and financial intermediation, Journal of Finance 32, 371-387.

Maksimovic, Vojislav, and Haluk Unal, 1993, Issue size choice and "underpricing" in thrift mutual-to-stock conversions, Journal of Finance 48, 1659-1692.

Masulis, Ronald W., 1987, Changes in ownership structure: Conversions of mutual savings and loans to stock charter, Journal of Financial Economics 18, 29-59.

Megginson, William L., 1990, Restricted voting stock, acquisition premiums, and the market value of corporate control, The Financial Review 25, 175-198.

Merrick, Bill, 2001, When CUs become banks, Credit Union Magazine 67, 48-54.

Ohlson, James A., 1995, Earnings, book values, and dividends in equity valuation, Contemporary Accounting Research 11, 661-687. 
Okuba, Makoto, 1999, MHCs: A global perspective, Insurance, Finance and Investment, February 8, 1999.

Palia, Darius, 1993, The managerial, regulatory, and financial determinants of bank merger premiums, Journal of Industrial Economics 41, 91-102.

Rhoades, Stephen A., 1987, Determinants of premiums paid in bank acquisitions, Atlantic Economic Journal 15, 20-30.

Ritter, Jay R., 1984, Signaling and the valuation of unseasoned new issues: A comment, Journal of Finance 39, 1231-1237.

Rogawski, Robert J., and Donald G. Simonson, 1989, Bank merger pricing premiums and interstate bidding, in Bank Mergers: Current Issues and Perspectives, Benton E. Gup (ed.), 87-106.

Rose, Peter S., 1991, Bidding theory and bank merger premiums: The impact of structural and regulatory factors, Review of Business and Economic Research 26, 2240.

Rydqvist, Kristian, 1996, Takeover bids and the relative prices of shares that differ in their voting rights, Journal of Banking and Finance 20, 1407-1425.

Shawky, Hanny, Tobias Kilb, and Carsten Staas, 1996, Determinants of bank merger premiums, Journal of Economics and Finance 20, 117-131.

Unal, Haluk, 1997, Regulatory misconceptions in pricing thrift conversions: A closer look at the appraisal process, Journal of Financial Services Research 11, 239-254.

Van der Goot, T., 1997, Valuing new issues, Thesis Publishers, Amsterdam.

Zingales, Luigi, 1995, What determines the value of corporate votes?, The Quarterly Journal of Economics 110, 1047-1073. 


\section{Table I}

Example of Wealth Transfer through Dividends

\begin{tabular}{|c|c|c|c|c|c|c|c|}
\hline \multirow[b]{2}{*}{ Year } & \multirow{2}{*}{$\begin{array}{c}\text { Full } \\
\text { Demutualization } \\
\text { All } \\
\text { Shareholders } \\
\text { (2 shares) }\end{array}$} & \multicolumn{3}{|c|}{$\begin{array}{l}\text { Mutual Holding Company } \\
\text { OTS Policy } \\
\text { (Before } 1995 \text { and after 2000) }\end{array}$} & \multicolumn{3}{|c|}{$\begin{array}{l}\text { Mutual Holding Company } \\
\text { OTS Policy } \\
\text { (Between } 1995 \text { and 2000) }\end{array}$} \\
\hline & & $\begin{array}{l}\text { MHC } \\
\text { Holders } \\
\text { (1 Share) } \\
\end{array}$ & $\begin{array}{l}\text { Minority } \\
\text { Shareholders } \\
\text { (1 Share) }\end{array}$ & $\begin{array}{l}\text { Combined } \\
\text { (2 Shares) }\end{array}$ & $\begin{array}{c}\text { MHC } \\
\text { Holders } \\
\text { (1 Share) } \\
\end{array}$ & $\begin{array}{l}\text { Minority } \\
\text { Shareholders } \\
\text { (1 Share) }\end{array}$ & $\begin{array}{l}\text { Combined } \\
\text { (2 Shares) }\end{array}$ \\
\hline 1 & $\$ 0.50$ & $\$ 0$ & $\$ 0.25$ & $\$ 0.25$ & $\$ 0$ & $\$ 0.25$ & $\$ 0.25$ \\
\hline 2 & 0.50 & 0 & 0.25 & 0.25 & 0 & 0.25 & 0.25 \\
\hline 3 & 0.50 & 0 & 0.25 & 0.25 & 0 & 0.25 & 0.25 \\
\hline 4 & 0.50 & 0 & 0.25 & 0.25 & 0 & 0.25 & 0.25 \\
\hline 5 & 20.00 & 10.64 & 10.64 & 21.28 & 11.28 & 10.00 & 21.28 \\
\hline PV @ 10\% & $\$ 14.00$ & $\$ 6.60$ & $\$ 7.40$ & $\$ 14.00$ & $\$ 7.00$ & $\$ 7.00$ & $\$ 14.00$ \\
\hline Value/Share & $\$ 7.00$ & $\$ 6.60$ & $\$ 7.40$ & $\$ 7.00$ & $\$ 7.00$ & $\$ 7.00$ & $\$ 7.00$ \\
\hline Value \% & $100 \%$ & $47 \%$ & $53 \%$ & $100 \%$ & $50 \%$ & $50 \%$ & $100 \%$ \\
\hline Premium & & & $6 \%$ & & & $0 \%$ & \\
\hline
\end{tabular}

Table II

Mutual-to-Stock Conversions by Year

\begin{tabular}{ccccc}
\hline Year & $\begin{array}{c}\text { All } \\
\text { MHC Conversions }\end{array}$ & $\begin{array}{c}\text { All } \\
\text { Full Conversions }\end{array}$ & $\begin{array}{c}\text { MHC Conversions } \\
\text { in Final Sample }\end{array}$ & $\begin{array}{c}\text { Full Conversions } \\
\text { in Final Sample }\end{array}$ \\
\hline 1988 & 1 & 14 & 1 & 12 \\
1989 & 0 & 3 & 0 & 2 \\
1990 & 0 & 8 & 0 & 5 \\
1991 & 0 & 9 & 0 & 4 \\
1992 & 5 & 24 & 4 & 19 \\
1993 & 7 & 41 & 5 & 37 \\
1994 & 15 & 57 & 14 & 45 \\
1995 & 6 & 57 & 6 & 51 \\
1996 & 2 & 56 & 2 & 53 \\
1997 & 4 & 29 & 4 & 28 \\
1998 & 14 & 38 & 13 & 30 \\
1999 & 9 & 17 & 8 & 15 \\
2000 & 4 & 10 & 4 & 10 \\
\hline Total & 64 & 329 & 61 & 311 \\
\hline
\end{tabular}




\section{Table III \\ Sample Statistics for non-MHCs and MHCs \\ $1988-2000$}

The Wilcoxon Rank-Sums, Two-Sample test is used to test for statistical difference in means. Significance for the two-sided test at the 1 percent, 5 percent, and 10 percent level are denoted by ${ }^{* * *}$, ${ }^{* *}$, and ${ }^{*}$.

\begin{tabular}{lrrrr}
\hline & \multicolumn{1}{c}{ Non- } & & & \\
& MHCs & MHCs & Z-value & P-value \\
\hline \# of firms & 311 & 61 & & \\
Ownership retained by MHC & $0 \%$ & $59.05 \%$ & & \\
NASDAQ traded & $78.78 \%$ & $78.69 \%$ & -0.01 & .9883 \\
Pre-conversion total assets (000s) & $\$ 343,065$ & $\$ 643,866$ & $2.73^{* * *}$ & .0064 \\
Conversion proceeds (000s) & $\$ 42,420$ & $\$ 30,375$ & $-5.16^{* * *}$ & .0001 \\
Pre-conversion equity (000s) & $\$ 24,437$ & $\$ 61,162$ & $4.43^{* * *}$ & .0001 \\
Conversion proceeds-to-pre-conversion equity & 1.8162 & 0.5308 & $-10.92^{* * *}$ & .0001 \\
Pre-conversion equity-to-assets & $7.80 \%$ & $9.71 \%$ & $4.30^{* * *}$ & .0001 \\
Pro-forma equity-to-assets & $22.11 \%$ & $14.57 \%$ & $-6.01^{* * *}$ & .0001 \\
Pro-forma return-on-assets & $0.59 \%$ & $0.78 \%$ & $2.52^{* *}$ & .0121 \\
Inside ownership in dollars (000s) & $\$ 1,872$ & $\$ 1,849$ & -1.44 & .1505 \\
Inside ownership purchased & $8.37 \%$ & $6.19 \%$ & $-2.76^{* * *}$ & .0058 \\
\% of firms with > 5\% inside ownership purchased & $65.27 \%$ & $54.10 \%$ & $-1.65^{*}$ & .0981 \\
\hline
\end{tabular}

\section{Table IV}

\section{Dividend Behavior of non-MHCs and MHCs}

Dividend behavior is measured in the first year after demutualization. Dividends yield is the company's first declared dividend annualized and divided by the company's book value per share. The Wilcoxon Rank-Sums, Two-Sample test is used to test for statistical difference in means. Significance for the twosided test at the 1 percent, 5 percent, and 10 percent level are denoted by ${ }^{* * *}$, ${ }^{* *}$, and ${ }^{*}$.

\begin{tabular}{lrrrr}
\hline & $\begin{array}{r}\text { Non- } \\
\text { MHCs }\end{array}$ & MHCs & Z-value & P-value \\
\hline & & & & \\
\# of Firms & 311 & 61 & & \\
Proportion of Companies Paying a Dividend & $73.63 \%$ & $93.44 \%$ & $3.35^{* * *}$ & .0008 \\
Dividend/Book Value (Dividend Yield) for All Firms & $1.43 \%$ & $3.33 \%$ & $8.07^{* * *}$ & .0001 \\
& & & & \\
\# of firms that Pay a Dividend & 229 & 57 & & \\
Dividend/Book Value (Dividend Yield) for Firms that Pay Dividends & $1.94 \%$ & $3.56 \%$ & $7.66^{* * *}$ & .0001 \\
\hline
\end{tabular}




\section{Table V \\ Analysis of Dividend Policy using Cross Sectional Regression}

The dependent variable is equal to (dividends per share divided by the book value per share) x 100 , where dividend is the company's first declared dividend annualized. For a mutual holding company the number of shares outstanding includes the shares held by minority stockholders and the shares held by the mutual holding company. Models 1 and 2 include the full sample. Model 3 limits the sample to dividend paying companies. ROA is calculated as (pro-forma net income divided by pro forma assets) x 100 . Equity-toassets is calculated as (pro-forma equity divided by pro-forma assets) $\mathrm{x} 100$. Size is proxied by the log of pro-forma assets. MHC is an indicator variable equal to one for mutual holding companies and zero otherwise. MHC after 1995 is an indicator variable equal to one for mutual holding companies that made their initial stock offering after February 1995 and zero otherwise. P-values are provided in parentheses. Statistical significances at the 1 percent, 5 percent, and 10 percent level are denoted by ${ }^{* * *},{ }^{* *}$, and ${ }^{*}$.

\begin{tabular}{|c|c|c|c|}
\hline & Model 1 & Model 2 & Model 3 \\
\hline Intercept & $\begin{array}{l}0.7234 \\
(.3539)\end{array}$ & $\begin{array}{l}1.0445 \\
(.1655)\end{array}$ & $\begin{array}{c}1.9097^{* *} \\
(.0125)\end{array}$ \\
\hline ROA & ${ }^{0.4269}$ & $\begin{array}{l}0.3222 \\
(.0060)^{* * *}\end{array}$ & $\begin{array}{l}0.3168 \\
(.0201)^{* *}\end{array}$ \\
\hline Equity-to-Assets & $\begin{array}{c}0.0264^{* * *} \\
(.0001)\end{array}$ & $\begin{array}{c}0.0309^{* * *} \\
(.0001)\end{array}$ & $\begin{array}{c}0.0118 \\
(.0925)^{*}\end{array}$ \\
\hline Log of Assets & $\begin{array}{l}-0.0110 \\
(.8551)\end{array}$ & $\begin{array}{l}-0.0407 \\
(.4829)\end{array}$ & $\begin{array}{c}-0.0394 \\
(.5099)\end{array}$ \\
\hline MHC & $\begin{array}{c}2.0253^{* * *} \\
(.0001)\end{array}$ & $\begin{array}{c}3.1593^{* * *} \\
(.0001)\end{array}$ & $\begin{array}{c}2.4980^{* * *} \\
(.0001)\end{array}$ \\
\hline MHC after 1995 & & $\begin{array}{c}-1.7588^{* * *} \\
(.0001)\end{array}$ & $\begin{array}{c}-1.3241^{* * *} \\
(.0001)\end{array}$ \\
\hline $\mathrm{R}^{2}$ & .3084 & .3623 & .3487 \\
\hline Adjusted $\mathrm{R}^{2}$ & .3009 & .3536 & .3340 \\
\hline F-value & 40.91 & 41.60 & 29.59 \\
\hline P-value & .0001 & .0001 & .0001 \\
\hline Observations & 372 & 372 & 286 \\
\hline
\end{tabular}




\section{Table VI}

\section{Change in Dividend Behavior within Firms as a Result of 1995 OTS Ruling}

In order to obtain consistent reporting of when dividends were paid relative to the OTS enforcement date, the sample is restricted to thrifts with data available on CRSP. If the firm paid semi-annually (quarterly, annually) prior to February 1, 1995 they were also required the firm to pay semi-annually (quarterly, annually) after February 1, 1995. Significance for T-value at the 1 percent, 5 percent, and 10 percent level are denoted by ${ }^{* * *},{ }^{* *}$, and ${ }^{*}$.

\begin{tabular}{|c|c|c|}
\hline 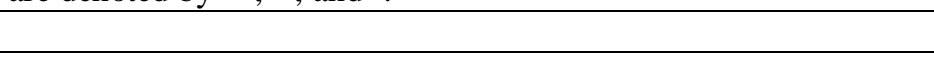 & MHCs & Non-MHCs \\
\hline Firms paying dividends & 8 & 42 \\
\hline Firms increasing dividend per share & 4 & 33 \\
\hline Percent increasing dividend per share & 0.5000 & 0.7857 \\
\hline T-value that the two proportions increasing dividends are equal & \multicolumn{2}{|c|}{$-1.995^{*}$} \\
\hline Firms decreasing dividend per share & 4 & 6 \\
\hline Percent decreasing dividend per share & 0.5000 & 0.1429 \\
\hline T-value that the two proportions decreasing dividends are equal & \multicolumn{2}{|c|}{$3.000^{* * *}$} \\
\hline
\end{tabular}

\section{Table VII}

\section{Pricing Information for non-MHCs and MHCs}

The book value per share is the pro-forma book value, incorporating the expected proceeds from the offering. For non-MHCs, the number of shares outstanding equals the shares issued. For MHCs, the number of shares outstanding includes the shares held by minority stockholders and the shares held by the mutual holding company. The Wilcoxon Rank-Sums Two-Sample test is used to test for statistical difference in means. Significance for the two sided test at the 1 percent, 5 percent, and 10 percent level are denoted by ${ }^{* * *},{ }^{* *}$, and ${ }^{*}$.

\begin{tabular}{lcccc}
\hline & Non- & & & \\
& MHCs & MHCs & Z-value & P-value \\
\hline \# of firms & & & & \\
Price-to-Book based on offer price & 311 & 61 & & \\
Price-to-Book based on $1^{\text {st }}$ Day Close & $64.79 \%$ & $93.50 \%$ & 8.49 & $.0001^{* * *}$ \\
Change in Price on $1^{\text {st }}$ Day. & $78.42 \%$ & $112.32 \%$ & 6.79 & $.0001^{* * *}$ \\
\hline
\end{tabular}




\section{Table VIII}

Analysis of Price-to-Book Ratios using Cross-Sectional Regression:

The dependent variable is equal to (the stock price divided by the company's pro-forma book value per share) $\mathrm{x} 100$. For a mutual holding company the number of shares outstanding includes shares held by minority stockholders and shares held by the mutual holding company. Models 1 and 3 define the stock price as the offer price and Models 2 and 4 define the stock price as the closing price at the end of the first day of trading. ROA is calculated as (pro-forma net income divided by pro-forma assets) x 100. Equity-toassets is calculated as (pro-forma equity divided by pro-forma assets) x 100 . Size is proxied by the log of pro-forma assets. Industry price-to-book is the average for all thrifts with available data on SNL at the beginning of the year in which the offer was made. MHC is an indicator variable equal to one for mutual holding companies and zero otherwise. MHC after 1995 is an indicator variable equal to one for mutual holding companies that made their initial stock offering after February 1995 and zero otherwise. Dividend yield is calculated as (dividends per share divided by the book value per share) x 100 , where dividends are equal to the company's first annualized dividend subsequent to the demutualization. The first dividend variable is equal to the dividend yield for non-MHCs and zero otherwise. The second dividend variable is equal to dividend yield for MHCs that made an initial stock offering prior to February 1, 1995. The third dividend variable is equal to dividend yield for MHCs making an initial stock offering after February 1, 1995. P-values are provided in parentheses. Statistical significances at the 1 percent, 5 percent, and 10 percent level are denoted by ${ }^{* * *},{ }^{* *}$, and ${ }^{*}$.

\begin{tabular}{|c|c|c|c|c|}
\hline & Model 1 & Model 2 & Model 3 & Model 4 \\
\hline & $\begin{array}{l}\text { Price-to-Book } \\
\text { Offering } \\
\text { Price }\end{array}$ & $\begin{array}{c}\text { Price-to-Book } \\
\mathbf{1}^{\text {st }} \text { Trading } \\
\text { Day Price }\end{array}$ & $\begin{array}{c}\text { Price-to-Book } \\
\text { Offering } \\
\text { Price }\end{array}$ & $\begin{array}{c}\text { Price-to-Book } \\
\mathbf{1}^{\text {st }} \text { Trading } \\
\text { Day Price }\end{array}$ \\
\hline Intercept & $\begin{array}{c}69.6980^{* * *} \\
(.0001)\end{array}$ & $\begin{array}{c}28.2964^{*} \\
(.0949)\end{array}$ & $\begin{array}{c}67.9363^{* * *} \\
(.0001)\end{array}$ & $\begin{array}{c}24.7130 \\
(.1439)\end{array}$ \\
\hline ROA & $\begin{array}{l}2.2809^{*} \\
(.0743)\end{array}$ & $\begin{array}{l}2.8263 \\
(.1825)\end{array}$ & $\begin{array}{l}1.7365 \\
(.1618)\end{array}$ & $\begin{array}{l}2.3679 \\
(.2680)\end{array}$ \\
\hline Equity-to-Assets & $\begin{array}{c}0.1906^{* *} \\
(.0212)\end{array}$ & $\begin{array}{c}0.6285^{* * *} \\
(.0001)\end{array}$ & $\begin{array}{c}0.1670^{* *} \\
(.0400)\end{array}$ & $\begin{array}{c}0.6023^{* * *} \\
(.0001)\end{array}$ \\
\hline Log of Assets & $\begin{array}{c}-1.8780^{* * * *} \\
(.0076)\end{array}$ & $\begin{array}{l}0.6893 \\
(.5537)\end{array}$ & $\begin{array}{c}-1.7688^{* * * *} \\
(.0086)\end{array}$ & $\begin{array}{l}0.9358 \\
(.4177)\end{array}$ \\
\hline Inside Ownership > 5\% & $\begin{array}{c}-6.9360^{* * *} \\
(.0001)\end{array}$ & $\begin{array}{l}-1.6881 \\
(.5223)\end{array}$ & $\begin{array}{c}-6.7220^{* * *} \\
(.0001)\end{array}$ & $\begin{array}{l}-1.1757 \\
(.6529)\end{array}$ \\
\hline Industry Price-to-Book & $\begin{array}{c}0.1704^{* * * *} \\
(.0001)\end{array}$ & $\begin{array}{c}0.2787^{* * * *} \\
(.0001)\end{array}$ & $\begin{array}{c}0.1686^{* * * *} \\
(.0001)\end{array}$ & $\begin{array}{c}0.2726^{* * * *} \\
(.0001)\end{array}$ \\
\hline MHC & $\begin{array}{c}34.6843^{* * *} \\
(.0001)\end{array}$ & $\begin{array}{c}43.9659^{* * * *} \\
(.0001)\end{array}$ & $\begin{array}{c}11.0110^{* * *} \\
(.0025)\end{array}$ & $\begin{array}{c}22.1679^{* * *} \\
(.0004)\end{array}$ \\
\hline MHC after February 1, 1995 & $\begin{array}{c}-11.8143^{* * *} \\
(.0010)\end{array}$ & $\begin{array}{c}-16.5682^{* * *} \\
(.0054)\end{array}$ & & \\
\hline Dividend Yield for Non-MHCs & & & $\begin{array}{l}0.9342 \\
(.1483)\end{array}$ & $\begin{array}{l}1.2072 \\
(.2781)\end{array}$ \\
\hline Dividend Yield for MHC prior to & & & $5.8473^{* * * *}$ & $5.1234^{* * * *}$ \\
\hline February 1, 1995 & & & $(.0001)$ & $(.0011)$ \\
\hline Dividend Yield for MHC after & & & $4.7926^{* * *}$ & 2.8556 \\
\hline February 1, 1995 & & & $(.0001)$ & $(.1216)$ \\
\hline $\mathrm{R}^{2}$ & .5217 & .4117 & .5611 & .4190 \\
\hline Adjusted $\mathrm{R}^{2}$ & .5125 & .4004 & .5502 & .4045 \\
\hline F-value & 56.71 & 36.40 & 51.42 & 29.00 \\
\hline P-value & .0001 & .0001 & .0001 & .0001 \\
\hline Observations & 372 & 372 & 372 & 372 \\
\hline
\end{tabular}




\section{Table IX}

Analysis of Price Increases at the Offer Date using Cross-Sectional Regression:

The dependent variable is equal to the one-day return at the initial public offering x 100. ROA is calculated as (proforma net income divided by pro-forma assets) x 100. Equity-to-assets which is calculated as (pro-forma equity divided by pro-forma assets) x 100. Size is proxied by the log of pro-forma assets. Industry price-to-book is the average for all thrifts with available data on SNL at the beginning of the year in which the offer was made. Price-tobook is defined as the offering price divided by pro-forma book value per share. The thrift index change is equal to the percentage change in the equal-weighted thrift index over the previous six weeks (30 trading days) using all thrifts available on the CRSP tapes, and interest rate change is the percentage change in interest rates over the previous six weeks. MHC is an indicator variable equal to one for mutual holding companies and zero otherwise. MHC after 1995 is an indicator variable equal to one for mutual holding companies that made their initial stock offering after February 1995 and zero otherwise. Dividend yield is calculated as (dividends per share divided by the book value per share) $\mathrm{x}$ 100, where dividends are equal to the company's first annualized dividend subsequent to the demutualization. The first dividend variable is equal to the dividend yield for non-MHCs and zero otherwise. The second dividend variable is equal to dividend yield for MHCs that made an initial stock offering prior to February 1, 1995 and zero otherwise. The third dividend variable is equal to dividend yield for MHCs making an initial stock offering after February 1, 1995 and zero otherwise. P-values are provided in parentheses. Statistical significances at the 1 percent, 5 percent, and 10 percent level are denoted by ${ }^{* * *},{ }^{* *}$, and ${ }^{*}$.

\begin{tabular}{|c|c|c|}
\hline & $\begin{array}{c}\text { Model 1 } \\
\text { One-Day } \\
\text { Return at the } \\
\text { IPO Date } \\
\end{array}$ & $\begin{array}{c}\text { Model } 2 \\
\text { One-Day } \\
\text { Return at the } \\
\text { IPO Date } \\
\end{array}$ \\
\hline Intercept & $\begin{array}{c}-84.7782^{* * *} \\
(.0001)\end{array}$ & $\begin{array}{c}-90.9567^{* * *} \\
(.0001)\end{array}$ \\
\hline ROA & $\begin{array}{l}0.1534 \\
(.9230)\end{array}$ & $\begin{array}{l}0.4774 \\
(.7640)\end{array}$ \\
\hline Equity-to-Assets & $\begin{array}{c}0.5304^{* * * *} \\
(.0001)\end{array}$ & $\begin{array}{c}0.5408^{* * *} \\
(.0001)\end{array}$ \\
\hline Log of Assets & $\begin{array}{c}4.3560^{* * *} \\
(.0001)\end{array}$ & $\begin{array}{c}4.6408^{* * *} \\
(.0001)\end{array}$ \\
\hline Inside Ownership > 5\% & $\begin{array}{c}8.8343^{* * *} \\
(.0001)\end{array}$ & $\begin{array}{c}9.5915^{* * *} \\
(.0001)\end{array}$ \\
\hline Industry Price-to-Book & $\begin{array}{l}0.1518^{* *} \\
(.0374)\end{array}$ & $\begin{array}{c}0.1385^{* * *} \\
(.0002)\end{array}$ \\
\hline Price-to-Book at the Offer Date & $\begin{array}{c}0.2055^{* * *} \\
(.0016)\end{array}$ & $\begin{array}{c}0.2640^{* * *} \\
(.0001)\end{array}$ \\
\hline Thrift Index Change & $\begin{array}{c}1.4485^{* * *} \\
(.0001)\end{array}$ & $\begin{array}{l}1.4683^{* *} \\
(.0001)\end{array}$ \\
\hline Interest Rate Change & $\begin{array}{c}-0.4431^{* * *} \\
(.0023)\end{array}$ & $\begin{array}{c}-0.4268^{* * *} \\
(.0031)\end{array}$ \\
\hline MHC & $\begin{array}{l}3.5821 \\
(.3927)\end{array}$ & $\begin{array}{l}5.2848 \\
(.2052)\end{array}$ \\
\hline MHC after February 1, 1995 & $\begin{array}{c}-9.3289^{* *} \\
(.0367)\end{array}$ & \\
\hline Dividend Yield for Non-MHCs & & $\begin{array}{l}-0.5274 \\
(.5215)\end{array}$ \\
\hline Dividend Yield for MHC prior to February 1, 1995 & & $\begin{array}{c}-1.5309 \\
(.2087)\end{array}$ \\
\hline Dividend Yield for MHC after February 1, 1995 & & $\begin{array}{c}-4.2996^{* * *} \\
(.0022)\end{array}$ \\
\hline $\mathrm{R}^{2}$ & .3416 & .3528 \\
\hline Adjusted $\mathrm{R}^{2}$ & .3234 & .3312 \\
\hline F-value & 18.73 & 16.31 \\
\hline P-value & .0001 & .0001 \\
\hline Observations & 372 & 372 \\
\hline
\end{tabular}




\section{Table X}

\section{Abnormal Returns Surrounding OTS Rulings}

Estimated equation: $R_{i t}=a_{i}+b_{i} R_{m t}+\sum_{j=-1}^{0} \gamma_{i, j} D_{j}+e_{i t} \cdot \mathrm{R}_{\mathrm{mt}}$ is the value-weighted index. The event window spans two days, including the day prior to the OTC ruling. The estimation period is 100 days, ending 5 days prior to the event.

\begin{tabular}{|c|c|c|c|c|c|}
\hline Event Dates & $\mathrm{N}$ & $\begin{array}{c}\text { Mean } \\
\text { Cumulative } \\
\text { Abnormal } \\
\text { Return }(-1,0)\end{array}$ & t-statistic & Pos : Neg & $\begin{array}{l}\text { Z-statistic }{ }^{\mathrm{a}} \\
\text { for signs test }\end{array}$ \\
\hline $\begin{array}{l}\text { May 15, } 1995 \\
\text { Prohibited MHCs from } \\
\text { waiving dividends }\end{array}$ & 21 & $-0.38 \%$ & 0.58 & $10: 11$ & -0.22 \\
\hline $\begin{array}{l}\text { July 12, } 2000 \\
\text { OTS allows waiver of } \\
\text { dividends (All MHCs) }\end{array}$ & 30 & $0.59 \%{ }^{* *}$ & 1.99 & $20: 10$ & $1.83^{*}$ \\
\hline $\begin{array}{l}\text { July 12, } 2000 \\
\text { OTS allows waiver of } \\
\text { dividends (MHCs not } \\
\text { previously grandfathered) }\end{array}$ & 24 & $0.82 \%{ }^{*}$ & 1.79 & $16: 8$ & 1.63 \\
\hline
\end{tabular}

a The z-statistic is determined as, $\left(G-N^{*} p\right) / \sqrt{N^{*} p(1-p)}$, where $G$ is the number of positive parameter estimates, $N$ is the total number of parameter estimates, and $p$ is the probability of a positive estimate $(0.50) . *^{* * *}$, and ${ }^{* * *}$ denote statistical significance at the $10 \%, 5 \%$, and $1 \%$ levels. 